\title{
Congenital Hypothyroidism: An Audit and Study of Different Cord Blood Screening TSH Values in a Tertiary Medical Centre in Malaysia
}

\author{
Sze Lyn Jeanne Wong, ${ }^{1}$ Muhammad Yazid Jalaludin, ${ }^{2}$ Azriyanti Anuar Zaini, \\ Nurshadia Samingan, ${ }^{2}$ and Fatimah Harun ${ }^{2}$ \\ ${ }^{1}$ Department of Paediatrics, Putrajaya Hospital, Malaysia \\ ${ }^{2}$ Department of Paediatrics, Faculty of Medicine, University Malaya, Malaysia
}

Correspondence should be addressed to Sze Lyn Jeanne Wong; jeanne938@yahoo.com and

Muhammad Yazid Jalaludin; yazidj@ummc.edu.my

Received 19 August 2015; Accepted 15 October 2015

Academic Editor: Sarantis Livadas

Copyright (C) 2015 Sze Lyn Jeanne Wong et al. This is an open access article distributed under the Creative Commons Attribution License, which permits unrestricted use, distribution, and reproduction in any medium, provided the original work is properly cited.

\begin{abstract}
Mothers are often discharged within 24 hours in most Asian countries. Therefore, our screening programs for congenital hypothyroidism $(\mathrm{CH})$ must consider the value of cord blood TSH. Our objectives were to compare the incidence of $\mathrm{CH}$, positive predictive values, and recall rates using different cord blood TSH values. We also reviewed the results of the second-screening program for premature babies. 99.7\% $(n=25,757)$ of all newborns were screened from 1st January 2009 to 31 st December 2013. Babies with cord blood TSH $>25 \mathrm{mIU} / \mathrm{L}$ or $20-25 \mathrm{mIU} / \mathrm{L}$ and FT4 $<20 \mathrm{pmol} / \mathrm{L}$ were recalled for a repeat venous TSH and FT4 on days 3-5 of life to confirm $\mathrm{CH}$. Twenty-two babies were confirmed to have $\mathrm{CH}$, an incidence of 1:1170. Five were premature. Eleven term babies had cord blood TSH $>30 \mathrm{mIU} / \mathrm{L}$ and six had values $25.1-30 \mathrm{mIU} / \mathrm{L}$. Lowering the recall cut-off value to $20 \mathrm{mIU} / \mathrm{L}$ would double the recall rate from $0.63 \%(n=163)$ to $1.3 \%(n=340)$ with no additional cases detected, whereas using $30 \mathrm{mIU} / \mathrm{L}$ would have missed $35 \%$ of cases. The incidence of $\mathrm{CH}$ was similar, 1:1515, when using either cut-off $20 \mathrm{mIU} / \mathrm{L}$ or cut-off $25 \mathrm{mIU} / \mathrm{L}$ but lower, 1:2380, when using $30 \mathrm{mIU} / \mathrm{L}$. We recommend the screening cord blood TSH cut-off should be $25 \mathrm{mIU} / \mathrm{L}$ and screening for premature babies should be continued.
\end{abstract}

\section{Introduction}

Most developed countries offer universal newborn thyroid screening because while $\mathrm{CH}$ is common and easily treatable, early symptoms or signs are often absent [1-6]. When clinical manifestations are evident there is already irreversible cognitive impairment, hence the importance of prompt recognition and adequate treatment [1-3,7-12].

Although there are universal $\mathrm{CH}$ screening guidelines, there are variations in screening strategies worldwide with regard to approach and timing $[1,7]$. A primary TSH strategy is used in most countries with the chief objective being to detect primary $\mathrm{CH}$. Some programs also measure T4 levels, for example, in the United States, Israel, Netherlands, and Japan $[1,7,9]$. Over the last decade, several newborn screening programs have reported that the incidence of $\mathrm{CH}$ has increased from 1:4000 to 1:2000, and lower TSH cut-offs appear to be the leading factor for this trend $[1,7,9,10,13-15]$. With lower TSH cut-offs, milder forms of $\mathrm{CH}$, which could be transient, have been detected and also potentially more false positives, which could give rise to increased economic and labor burden $[7,9]$. When the TSH cut-off was lowered from a range of $>20-25 \mathrm{mIU} / \mathrm{L}$ to $6-10 \mathrm{mIU} / \mathrm{L}$ on a repeated 2nd screening, screening programs reported a doubling of the incidence of $\mathrm{CH}$ in Western Australia, Lombardy (Italy), North England, Greece, Quebec, and Brazil [7].

Besides approach, the timing of sample collection is also an important consideration. In most developed countries, 
blood samples are captured on filter paper and are obtained after 24 hours of life $[1,7,9]$. The ideal collection is between days 3 and 5 of life because a surge in neonatal TSH, and consequently $\mathrm{T} 4$, occurs within minutes of birth and subsides to baseline over the next 24-72 hours [1-3, 7, 9, 16-18]. Hence, a 2nd screening is recommended if the specimen was collected within 24 hours of life to reduce the number of false positives [1-3, 7, 9].

However, in many developing Asian countries including Malaysia, mothers and their infants are often discharged from hospital within 24 hours of delivery and would return to their rural hometowns $[10,11,19]$. Therefore we should consider the value of cord blood TSH for screening rather than the more ideal use of TSH at 72 hours after birth. Information about the incidence, positive predictive value, detection, and recall rates using different cord blood TSH cut-off values would hence be important to improve our screening programs within our resources and local context. It is also practical in Malaysia as there is already an established local screening program for glucose-6-phosphate dehydrogenase (G6PD) deficiency using cord blood $[10,11,20]$.

Screening for $\mathrm{CH}$ using cord blood $\mathrm{TSH}$ was started in University Malaya Medical Centre (UMMC), a tertiary medical centre in Malaysia, since August 1987. This was followed by a nationwide stepwise screening program for all babies delivered in the public hospitals [10]. In 2012, a secondscreening program in UMMC involving venous TSH and fT4 was initiated for premature babies after their first week of life, as these babies may present with delayed TSH rise.

\section{Methods}

This study is descriptive and retrospective in nature. An audit of the newborn screening program in UMMC over a fiveyear period from 1st January 2009 to 31st December 2013 was performed. The total number of live births was obtained from the hospital's annual birth delivery book. Details of babies screened for $\mathrm{CH}$ during this period were obtained from the $\mathrm{CH}$ database of the paediatric endocrine clinic and medical records of babies with confirmed $\mathrm{CH}$ were retrospectively reviewed.

All live newborns had $3 \mathrm{~mL}$ of their cord blood taken in plain tubes and sent to the laboratory, where at least $100 \mu \mathrm{L}$ of serum was obtained. The serum was assayed for TSH using an automated immune chemiluminescence assay system (Siemens). The functional sensitivity for TSH was $0.008 \mathrm{mIU} / \mathrm{L}$, and analytical sensitivity for FT4 was $1.3 \mathrm{pmol} / \mathrm{L}$. The results were stored in $\mathrm{CH}$ database and managed by the same medical laboratory technologist throughout the study period. The same technologist did the recall of patients and tracing of repeat venous samples. All babies with $\mathrm{CH}$ were followed up by the same consultant and her team.

The following cord blood TSH values were considered abnormal and were recalled for confirmation of $\mathrm{CH}$ with a repeat venous sample of TSH and FT4 at days 3 to 5 of life:

(i) cord blood TSH $>25 \mathrm{mIU} / \mathrm{L}$ or

(ii) cord blood TSH 20-25 mIU/L and cord blood FT4< $20 \mathrm{pmol} / \mathrm{L}$.
From 2012, premature babies of less than 37-week gestation were screened for $\mathrm{CH}$ via neonatal cord blood TSH with a second screening of weekly serum TSH and FT4 for 4 weeks.

Babies were confirmed to have $\mathrm{CH}$ and started on Lthyroxine if the repeat venous $\mathrm{TSH}$ was $>20 \mathrm{mIU} / \mathrm{L}$ or the venous TSH was $>10 \mathrm{mIU} / \mathrm{L}$ and the FT4 $<20 \mathrm{pmol} / \mathrm{L}$ after day 3 of life.

Babies born to foreigners and babies born before arrival at UMMC were excluded from this study. Babies who were confirmed to have $\mathrm{CH}$ received treatment with L-thyroxine $(10-15 \mathrm{mcg} / \mathrm{kg} /$ day) as soon as the diagnosis was made and were followed up monthly in the first year to ensure their TSH was less than $5 \mathrm{mIU} / \mathrm{L}$, preferably between 0.5 and $2.5 \mathrm{mIU} / \mathrm{L}$ $[2,7]$, and their FT4 was in the upper normal reference range for their age. In the second year, they were seen 2-3 monthly until they were 3 years old, when L-thyroxine was temporarily stopped for 4-6 weeks followed by a technetium thyroid scan. On the day prior to the thyroid scan, blood tests for TSH and FT4 were repeated to determine if there was an increase in $\mathrm{TSH}>8 \mathrm{mIU} / \mathrm{L}$ and a fall in FT4 below the normal reference range. L-thyroxine would be resumed if there was a rise in TSH despite the presence of a normal thyroid gland as seen on the thyroid scan.

In this study our objectives were to compare the incidence and positive predictive values and recall rates using different cut-off cord blood TSH values of $20 \mathrm{mIU} / \mathrm{L}, 25 \mathrm{mIU} / \mathrm{L}$, and $30 \mathrm{mIU} / \mathrm{L}$. We also studied the results of the second screening for premature babies and reviewed the profiles of all infants diagnosed with $\mathrm{CH}$ with respect to their cord blood TSH and repeat venous TSH and FT4 and treatment and thyroid scan results.

\section{Results}

A total of 25,757 (99.7\%) out of 25,834 live newborns were screened during the 5-year period, from 1st January 2009 to 31st December 2013. This figure compares favourably with other developed countries, for example, Western Australia (99\%) and Scotland (99.9\%) [10].

Twenty-two babies were confirmed to have $\mathrm{CH}$ and were treated during this period. This gave an overall incidence of 1 in 1170, higher than that in previous local studies and other Asian countries [7, 10, 11]; see Table 1 .

Of the 22 babies, five were premature and were detected to have $\mathrm{CH}$ by the 2 nd-screening program. Of the 17 treated term babies, all had cord blood TSH $>25 \mathrm{mIU} / \mathrm{L}$. The number of term babies confirmed with $\mathrm{CH}$ with respect to their cord blood TSH and FT4 values is summarised in Table 2.

Of the 17 term babies who were treated, four were no longer under our follow-up. All of the 13 babies who were still under our follow-up continued to receive L-thyroxine, except for one patient whose medication was stopped at 13 months of age when the TSH was very suppressed despite taking a very low dose of thyroxine. The thyroid function remained normal when L-thyroxine was discontinued. This particular patient had a cord blood TSH of $25.43 \mathrm{mIU} / \mathrm{L}$ and a repeat venous blood TSH of $26.39 \mathrm{mIU} / \mathrm{L}$ and FT4 of $16.2 \mathrm{pmol} / \mathrm{L}$ on day 5 of life. Six patients had their thyroid scan performed at 3 years of age. One patient had an absent (agenesis) thyroid gland, and 
TABlE 1: Comparison of incidences of $\mathrm{CH}$ reported in Asian countries and from local studies in Malaysia.

\begin{tabular}{lcccc}
\hline Country & $\begin{array}{c}\text { Total } \\
\text { screened }\end{array}$ & Year & $\begin{array}{c}\text { Cases } \\
\text { detected }\end{array}$ & Incidence \\
\hline Malaysia & & & & \\
$\quad$ Harun F. & 19281 & 1992 & 7 & $1: 2754$ \\
Amar HSS & 8950 & 1997 & 3 & $1: 2985$ \\
Wu L. L. & 11000 & 1995 & 3 & $1: 3666$ \\
$\quad$ Mafauzy & 12261 & NA & 4 & $1: 3065$ \\
$\quad$ Wong S. L. J. & 25757 & 2014 & 22 & $1: 1170$ \\
Thailand & 647000 & 1992 & 430 & $1: 3314$ \\
Philippines & 577000 & 1996 & 48 & $1: 3678$ \\
Hong Kong & 65000 & 2003 & 27 & $1: 5681$ \\
Laos & 14000 & 2008 & 2 & $1: 2047$ \\
China & 10700000 & 2012 & 5227 & $1: 2404$ \\
\hline
\end{tabular}

${ }^{*}$ Overall incidence including 5 premature babies detected by 2 nd screening.

TABLE 2: Number of term babies with confirmed $\mathrm{CH}$ with respect to their cord blood TSH and FT4.

\begin{tabular}{lc}
\hline Cord blood TSH (mIU/L) & $\begin{array}{c}\text { Number of confirmed CH cases } \\
(n=17)\end{array}$ \\
\hline$>30$ & $11(65 \%)$ \\
$25.1-30$ & $6(35 \%)$ \\
$20-25$ & 0 \\
\hline
\end{tabular}

another had a sublingual thyroid. The remaining four (66\%) patients showed normal technetium thyroid uptake on their scans. Table 3 shows the clinical profiles of the term babies with confirmed $\mathrm{CH}$.

The recall rate using a cord blood TSH cut-off of $25 \mathrm{mIU} / \mathrm{L}$ was $0.63 \%(n=163)$. The lower cut-off of $20 \mathrm{mIU} / \mathrm{L}$ had a low positive predictive value; the recall rate would double to $1.3 \%(n=340)$ but no additional cases would be detected. Although the majority, $65 \%(n=11)$, of babies with $\mathrm{CH}$ had a cord blood TSH $>30 \mathrm{mIU}$, using this cut-off would have missed $35 \%(n=6)$ of cases. The incidence of positive $\mathrm{CH}$ cases is the same, 1 in 1515, for both TSH cut-off values of either 25 or $20 \mathrm{mIU} / \mathrm{L}$. However, the incidence is lower, 1 in 2341, if $30 \mathrm{mIU} / \mathrm{L}$ is used. Comparisons between different TSH cut-offs 20,25, and $30 \mathrm{mIU} / \mathrm{L}$ are summarised in Table 4.

All premature babies who were detected to have $\mathrm{CH}$ by the second screening of their weekly TFT after the first week of life had normal cord blood TSH and would have been missed if the second screening was not carried out. These babies had a delayed TSH rise after their first week of life (see Table 5).

\section{Discussion}

The overall incidence of 1:1170 $(N=25757)$ newborns with $\mathrm{CH}$ reported in UMMC over a five-year period from 1st January 2009 to 31st December 2013 is much higher than the previously reported local prevalence of 1:3117, based on pooled data from four local studies (one from a public hospital and three from local university hospitals) collected between 1991 and $1997[10,11]$. The incidence is also higher than in other Asian countries, which have reported a range from 1:2000 to 1:5000 [7]. Possible reasons for the higher incidence could be the result of enhanced detection of neonates with mild disease due to the lower screening cut-off TSH values use compared to other hospitals, higher successful recall rates (UMMC is located in an urban area as opposed to rural areas where there may be difficulties to contact the family), different population ethnic composition, environmental factors, and the 2nd screening of premature infants detecting those with delayed TSH rise. This is also consistent with worldwide reports of doubling of the incidence of $\mathrm{CH}$ with lowering of the screening TSH cut-off and changes in birth demographics [7]. Even if the premature babies were excluded, the incidence rate for term babies during this study period is still high at 1:1515.

The incidence of $\mathrm{CH}$ is similar, 1 in 1515, regardless of whether a lower cut-off $20 \mathrm{mIU} / \mathrm{L}$ is used instead of $25 \mathrm{mIU} / \mathrm{L}$. However, there is a lower incidence, 1 in 2341, if a higher cut-off value $30 \mathrm{mIU} / \mathrm{L}$ is used. Lowering the cut-off value from 25 to $20 \mathrm{mIU} / \mathrm{L}$ would have doubled the recall rate from $0.63 \%(n=163)$ to $1.3 \%(n=340)$ with no additional cases detected for twice the extra workload. The majority $(65 \%, n=11)$ of babies with $\mathrm{CH}$ had a cord blood TSH $>30 \mathrm{mIU} / \mathrm{L}$ with a lower recall rate of $0.3 \%$ $(n=84)$. Hence, using this higher cut-off of $30 \mathrm{mIU} / \mathrm{L}$ may seem attractive in terms of cost and workload but it should not be recommended because a high percentage $(35 \%, n=$ 6 ) of the cases would have been missed. The recall rate of $0.6 \%$ for a cut-off of $>25 \mathrm{mIU} / \mathrm{L}$ is acceptable and is similar to other countries' screening programs that use a primary TSH approach (reported 0.03 to $0.8 \%$ ) $[1,14,19]$. Primary TSH screening has been reported to have a false positive rate ranging from $0.65 \%$, in a screening program that applies $25 \mathrm{mIU} / \mathrm{L}$ cut-off, to $2.6 \%$ in a program applying $18 \mathrm{mIU} / \mathrm{L}$ cut-off $[9,21]$. In comparison, our false positive rate was slightly lower at $0.56 \%$ for the $25 \mathrm{mIU} / \mathrm{L}$ cut-off and $1.2 \%$ for the $20 \mathrm{mIU} / \mathrm{L}$.

A retrospective review of our patients' records revealed that, of the seventeen term babies who were treated, four were no longer under our follow-up. We are unsure if they had defaulted on follow-up or had transferred care to another centre, as attempts to contact them failed. Of the remaining thirteen who were still under follow-up, one patient had transient $\mathrm{CH}$. This patient is currently 2 years old and successfully stopped taking L-thyroxine at 13 months. As reevaluation of treatment and thyroid scan is routinely done only at the age of three years, when most thyroid hormone dependent brain development is complete, only six patients have had their thyroid scan performed. One scan was reported as absence (agenesis) of thyroid glands, another one showed a sublingual thyroid, and the remaining four (66\%) scans were reported as normal (normal size, location, and uptake). An early thyroid scan at diagnosis during the neonatal period is not done routinely in hospitals in Malaysia because of limited resources.

Although it was not one of our objectives, it would be interesting to investigate further the aetiology of $\mathrm{CH}$ in our 
TABLE 3: Clinical profile of term babies with confirmed $\mathrm{CH}$ on follow-up.

\begin{tabular}{|c|c|c|c|c|c|c|c|c|c|c|}
\hline \multirow[t]{2}{*}{ Number } & \multirow[t]{2}{*}{ Sex } & \multirow[t]{2}{*}{ Ethnicity } & \multirow[t]{2}{*}{$\begin{array}{l}\text { Cord blood } \\
\text { TSH (mIU/L) }\end{array}$} & \multicolumn{2}{|c|}{$\begin{array}{l}\text { Venous blood at days } \\
\qquad 3-5\end{array}$} & \multirow[t]{2}{*}{$\begin{array}{c}\text { Current } \\
\text { age (years) }\end{array}$} & \multirow[t]{2}{*}{$\begin{array}{l}\text { Thyroid scan } \\
\text { (performed at } 3 \\
\text { years of age) }\end{array}$} & \multicolumn{2}{|c|}{$\begin{array}{l}\text { TFT results after } \\
4 \text { weeks' } \\
\text { cessation of } \\
\text { L-thyroxine at } 3 \\
\text { years of age }\end{array}$} & \multirow[t]{2}{*}{ Comment } \\
\hline & & & & $\begin{array}{c}\text { TSH } \\
(\mathrm{mIU} / \mathrm{L})\end{array}$ & $\begin{array}{c}\text { FT4 } \\
(\mathrm{pmol} / \mathrm{L})\end{array}$ & & & TSH & FT4 & \\
\hline 1 & $\mathrm{~F}$ & M & 26.44 & 25.17 & 16.5 & 4 & Normal & 20.42 & 10.5 & \\
\hline 2 & $\mathrm{~F}$ & M & 101.09 & 39 & 14.9 & 5 & Absent glands & 193.7 & 7.2 & \\
\hline 3 & M & $\mathrm{C}$ & 28.64 & 14.37 & 20.7 & 5 & Normal & 26.69 & 13.3 & \\
\hline 4 & M & M & 167.4 & 259.5 & 8.4 & 3.5 & Normal & 7.4 & 23 & \\
\hline 5 & $\mathrm{M}$ & $\mathrm{C}$ & 28.73 & 22.67 & 21 & 4 & Normal & 43.58 & 29.9 & \\
\hline 6 & $\mathrm{~F}$ & M & 362.2 & 150 & 13 & 3.5 & $\begin{array}{l}\text { Sublingual } \\
\text { thyroid }\end{array}$ & 521 & 4.5 & \\
\hline 7 & $\mathrm{~F}$ & M & 25.45 & 26.39 & 27.6 & 2 & NA & $\mathrm{N} A$ & & $\begin{array}{l}\text { L-thyroxine } \\
\text { stopped at } \\
13 \text { months of } \\
\text { age }\end{array}$ \\
\hline 8 & M & M & 28 & 19.3 & 20 & 3 & NA & $\mathrm{N} A$ & & $\begin{array}{c}\text { Down } \\
\text { syndrome }\end{array}$ \\
\hline 9 & $\mathrm{~F}$ & $\mathrm{C}$ & 30.69 & 34.78 & 15.3 & 2 & NA & $\mathrm{N} A$ & & \\
\hline 10 & $\mathrm{~F}$ & M & 30.49 & 14.86 & 24 & 2 & NA & $\mathrm{NA}$ & & \\
\hline 11 & $\mathrm{~F}$ & M & 360 & 377 & 9.3 & 1.5 & NA & $\mathrm{N} A$ & & \\
\hline 12 & $\mathrm{~F}$ & $\mathrm{C}$ & 75.76 & 69.7 & NA & 1.5 & NA & $\mathrm{N} A$ & & $\begin{array}{c}\text { Mild speech } \\
\text { delay, } \\
\text { widened AF }\end{array}$ \\
\hline 13 & $\mathrm{M}$ & $\mathrm{M}$ & 70.59 & 139.7 & 16.7 & 0.75 & NA & $\mathrm{N} A$ & & \\
\hline 14 & $\mathrm{~F}$ & I & 96.73 & 58.1 & 16.8 & 5 & - & - & & $\begin{array}{l}\text { Defaulted } \\
\text { follow-up }\end{array}$ \\
\hline
\end{tabular}

Sex: M: male and F: female. Ethnicity: M: Malay and C: Chinese.

None of the patients were noted to have developmental delay except for patient number 12. All were still on L-thyroxine except for patient number 7 .

TABLE 4: Comparison of different screening cut-off values.

\begin{tabular}{lccccc}
\hline $\begin{array}{l}\text { Cord blood TSH } \\
\text { cut-off }(\mathrm{mIU} / \mathrm{L})\end{array}$ & $\begin{array}{c}\text { Positive screened } \\
(\text { recall rates) } \\
(n=25757)\end{array}$ & $\begin{array}{c}\text { True positives } \\
\text { (confirmed CH by } \\
\text { repeated TFT at } \\
\text { days 3-5) }\end{array}$ & $\begin{array}{c}\text { False } \\
\text { positives }\end{array}$ & $\begin{array}{c}\text { Positive } \\
\text { predictive value }\end{array}$ & $\begin{array}{c}\text { Incidence } \\
\text { False positive } \\
\text { rate }\end{array}$ \\
\hline$>30$ & $84(0.32 \%)$ & 11 & 73 & $13 \%$ & $1: 2341$ \\
$>25$ & $163(0.63 \%)$ & 17 & 146 & $10.6 \%$ & $1: 1515$ \\
$>20$ & $340(1.3 \%)$ & 17 & 323 & $5 \%$ & $1: 1515$ \\
\hline
\end{tabular}

patients. The commonest permanent cause of $\mathrm{CH}$ reported was dysgenesis of the thyroid gland; however dyshormonogenesis among the Asian population has recently been shown to be a significant cause of $\mathrm{CH}[3,8,13,15,22-26]$. In our audit, $66 \%(n=4)$ of our permanent $\mathrm{CH}$ patients had normal thyroid scans. All were restarted on thyroxine because of TSH rise $>8 \mathrm{mIU} / \mathrm{L}$ after a month's trial of stopping medication at 3 years of age. The possible cause for this group of patients with normal scans was dyshormonogenesis. Mutations in the thyroid peroxidase (TPO) gene are known to be responsible for the majority of cases of $\mathrm{CH}$ with dyshormonogenetic glands [23, 25-27]. However, the number of patients is too small to draw any conclusions, and genetic studies have yet to be performed on these patients.

International guidelines recommend a second-screening specimen at 2 to 6 weeks of life for high risk groups, premature, LBW, VLBW, ill babies, or multiple births, as these babies may present with delayed TSH rise [1-3, 28, 29]. Possible reasons for the delayed TSH rise include immaturity of the hypothalamic-pituitary axis, medications such as dopamine or steroids, use of iodine for procedures, and unwell babies ("sick thyroid syndrome") [1-3, 28, 29]. For premature babies, serial screening should be considered at 2, 6, and 10 weeks of age or until they reach $1500 \mathrm{~g}$ or at discharge [1-3, 28, 29]. 
TABLE 5: Clinical profiles of premature babies with $\mathrm{CH}$.

\begin{tabular}{|c|c|c|c|c|c|c|c|c|}
\hline Patient & $\begin{array}{l}\text { Gestation } \\
\text { (weeks) }\end{array}$ & $\begin{array}{l}\text { Birth weight } \\
\text { (g) }\end{array}$ & Sex & $\begin{array}{l}\text { Cord blood } \\
\text { TSH (mIU/L) }\end{array}$ & $\begin{array}{c}\text { TSH }(\mathrm{mIU} / \mathrm{L}) \\
\text { FT4 }(\mathrm{pmol} / \mathrm{L}) \\
\text { values } \\
\text { at week of } \\
\text { diagnosis }\end{array}$ & $\begin{array}{c}\text { Current } \\
\text { age } \\
\text { (months) }\end{array}$ & $\begin{array}{l}\text { Current dose } \\
\text { of L-thyroxine } \\
\text { (mcg/day) }\end{array}$ & $\begin{array}{l}\text { Current } \\
\text { status }\end{array}$ \\
\hline 1 & 28 & 750 & M & 10.52 & $\begin{array}{c}\text { TSH 42, FT4 } 8.6 \\
\text { at week } 2\end{array}$ & 15 & 25 & $\begin{array}{c}\text { Normal } \\
\text { development }\end{array}$ \\
\hline 2 & 29 & 1100 & M & 10.2 & $\begin{array}{c}\text { TSH } 15.8, \\
\text { FT4 } 17 \\
\text { at week } 2\end{array}$ & 11 & 25 & $\begin{array}{c}\text { Normal } \\
\text { development }\end{array}$ \\
\hline 3 & 24 & 595 & $\mathrm{~F}$ & 5.25 & $\begin{array}{c}\text { TSH 105, } \\
\text { FT4 } 6.3 \\
\text { at week } 4 \\
\end{array}$ & 24 & 25 alt 37.5 & $\begin{array}{c}\text { Normal } \\
\text { development }\end{array}$ \\
\hline 4 & 34 & 1180 & $\mathrm{~F}$ & 9.07 & $\begin{array}{l}\text { TSH 138.9, } \\
\text { FT4 5.5 } \\
\text { at week } 2 \\
\end{array}$ & 16 & 37.5 & Speech delay \\
\hline 5 & 32 & 940 & M & 1.38 & $\begin{array}{c}\text { TSH 25.27, } \\
\text { FT4 } 17.3 \\
\text { at week } 2\end{array}$ & 34 & 25 & Normal \\
\hline
\end{tabular}

${ }^{*}$ All are still on thyroxine.

However, due to limited resources and the cost, this is not done routinely in most hospitals in Malaysia. In UMMC, a second-screening program for premature babies (gestation less than 37 weeks) has been in place since 2012, where venous TFT (both FT4 and TSH) is done every week until 4 weeks of life. To date, there have been five premature babies diagnosed with $\mathrm{CH}$, and their birth weights were all less than $1500 \mathrm{~g}$. All except one had normal cord blood TSH values $(<25 \mathrm{mIU} / \mathrm{L})$ and presented later with delayed TSH rise after 1 week of life. From our review of clinic notes, all the premature babies were confirmed to have $\mathrm{CH}$ and are still on L-thyroxine and under regular follow-up. No thyroid scan has been done yet as they are currently still younger than 3 years of age. One patient has speech delay, which could be due to a complication of both prematurity and hypothyroidism.

Our findings of five premature babies with permanent $\mathrm{CH}$ who had significant delayed TSH rise support the existing guidelines that a 2 nd screening for premature babies should be considered in Malaysia [1, 28, 29]. However, the sample size is small and, for it to be implemented, further studies to analyse the cost-effectiveness and long term follow-up for this group of babies are needed.

\section{Conclusion}

The overall incidence of CH in UMMC from 1st January 2009 to 31st December 2013 was 1:1170 ( $n=25,757)$ newborns, which is nearly three times higher than previously reported in Malaysia. Lowering the cut-off for cord blood TSH from 25 to $20 \mathrm{mIU} / \mathrm{L}$ would have doubled the recall rate and found no additional babies with $\mathrm{CH}$. Using a cut-off of $>30 \mathrm{mIU} / \mathrm{L}$ had a lower recall rate but would have missed $35 \%$ of cases. Based on this, we recommend that the screening cord blood TSH cut-off should be $25 \mathrm{mIU} / \mathrm{L}$. Screening of cord blood FT4 for borderline TSH $20-25 \mathrm{mIU} / \mathrm{L}$ to detect $\mathrm{CH}$ may be discontinued as it has a low positive predictive value.
Screening for premature babies should continue with weekly TFT from the 2 nd week of life.

\section{Abbreviations}

$\mathrm{CH}$ : Congenital hypothyroidism

TSH: Thyroid stimulating hormone

FT4: $\quad$ Free T4

TFT: Thyroid function test

LBW: Low birth weight

VLBW: Very low birth weight

UMMC: University Malaya Medical Centre.

\section{Conflict of Interests}

The authors declare that they have no conflict of interests.

\section{Acknowledgment}

Rosmini Tahir, Medical Laboratory Technologist, Department of Paediatrics, University Malaya Medical Centre, and Datuk Dr. Noor Hisham Abdullah, Director General of Health Malaysia, are acknowledged.

\section{References}

[1] J. Léger, A. Olivieri, M. Donaldson et al., "European society for paediatric endocrinology consensus guidelines on screening, diagnosis, and management of congenital hypothyroidism," The Journal of Clinical Endocrinology \& Metabolism, vol. 99, no. 2, pp. 363-384, 2014.

[2] S. R. Rose, R. S. Brown, T. Foley et al., "Update of newborn screening and therapy for congenital hypothyroidism," Pediatrics, vol. 117, no. 6, pp. 2290-2303, 2006.

[3] C. Larson and S. Radovick, Pediatric Endocrinology: A Practical Clinical Guide, Humana Press, 2nd edition, 2013. 
[4] A. Grüters, A. Jenner, and H. Krude, "Long-term consequences of congenital hypothyroidism in the era of screening programmes," Best Practice \& Research: Clinical Endocrinology \& Metabolism, vol. 16, no. 2, pp. 369-382, 2002.

[5] D. A. Fisher, "Disorders of the thyroid in the newborn and infant," in Clinical Pediatric and Adolescent Endocrinology, p. 164, Saunders, Philadelphia, Pa, USA, 2002.

[6] S. H. LaFranchi, "Newborn screening for congenital hypothyroidism: recommended guidelines," Thyroid, vol. 3, no. 3, pp. 257-263, 1993.

[7] G. Ford and S. H. Lafranchi, "Screening for congenital hypothyroidism: a worldwide view of strategies," Best Practice \& Research: Clinical Endocrinology and Metabolism, vol. 28, no. 2, pp. 175-187, 2014.

[8] B. B. Albert, W. S. Cutfield, D. Webster et al., "Etiology of increasing incidence of congenital hypothyroidism in New Zealand from 1993-2010," The Journal of Clinical Endocrinology \& Metabolism, vol. 97, no. 9, pp. 3155-3160, 2012.

[9] L. D. Madison and S. LaFranchi, "Screening for congenital hypothyroidism: current controversies," Current Opinion in Endocrinology \& Diabetes, vol. 12, no. 1, pp. 36-41, 2005.

[10] A. L. Zarina, R. Rahmah, K. M. Bador, S. F. Ng, and L. L. Wu, "Audit of newborn screening programme for congenital hypothyroidism," Medical Journal of Malaysia, vol. 63, no. 4, pp. 325328, 2008.

[11] A. Singh, "TSH screening of cord blood in Malaysia-its impact (the National Congenital Hypothyroid Screening Programme in Malaysian)," The Journal of Clinical Endocrinology \& Metabolism, vol. 1, no. 1, 2010.

[12] B. B. Albert, N. Heather, J. G. Derraik et al., "Neurodevelopmental and body composition outcomes in children with congenital hypothyroidism treated with high-dose initial replacement and close monitoring," Journal of Clinical Endocrinology and Metabolism, vol. 98, no. 9, pp. 3663-3670, 2013.

[13] M. L. Mitchell, H.-W. Hsu, and I. Sahai, "The increased incidence of congenital hypothyroidism: fact or fancy?" Clinical Endocrinology, vol. 75, no. 6, pp. 806-810, 2011.

[14] A. Simon and M. Zacharin, "Thyroid disorders", in Practical Pediatric Endocrinology in a Limited Resource Setting, pp. 5665, Elsevier, 2011.

[15] C. Corbetta, G. Weber, F. Cortinovis et al., "7-year experience with low blood TSH cutoff levels for neonatal screening reveals an unsuspected frequency of congenital hypothyroidism (CH)," Clinical Endocrinology, vol. 71, no. 5, pp. 739-745, 2009.

[16] K. Kawahara and S. Yokoya, "Establishment of reference intervals of thyrotropin and free thyroid hormones during the first week of life," Clinical Pediatric Endocrinology, vol. 11, no. 1, pp. $1-9,2002$.

[17] D. R. Dufour, "Laboratory tests of thyroid function: uses and limitations," Endocrinology and Metabolism Clinics of North America, vol. 36, no. 3, pp. 579-594, 2007.

[18] D. Zurakowski, J. Di Canzio, and J. A. Majzoub, "Pediatric reference intervals for serum thyroxine, triiodothyronine, thyrotropin, and free thyroxine," Clinical Chemistry, vol. 45, no. 7 , pp. 1087-1091, 1999.

[19] M. Hettiarachchi and S. Amarasena, "Indicators of newborn screening for congenital hypothyroidism in Sri Lanka: program challenges and way forward," BMC Health Services Research, vol. 14, article 385, 2014.

[20] Malaysian Paediatric Protocol, 3rd edition, 2013.
[21] F. Delange, "Neonatal screening for congenital hypothyroidism: results and perspectives," Hormone Research, vol. 48, no. 2, pp. 51-61, 1997.

[22] A. Hanukoglu, K. Perlman, I. Shamis, L. Brnjac, J. Rovet, and D. Daneman, "Relationship of etiology to treatment in congenital hypothyroidism," Journal of Clinical Endocrinology and Metabolism, vol. 86, no. 1, pp. 186-191, 2001.

[23] C. C. Lee, F. Harun, M. Y. Jalaludin et al., "A novel, homozygous c.1502T $>$ G (p.Val501Gly) mutation in the Thyroid peroxidase gene in Malaysian sisters with congenital hypothyroidism and multinodular goitre," International Journal of Endocrinology, vol. 2013, Article ID 987186, 7 pages, 2013.

[24] A. Gruters, "Congenital hypothyroidism," Pediatric Annals, vol. 21, pp. 15, 18-21, 24-28, 1992.

[25] C. C. Lee, F. Harun, M. Y. Jalaludin, C. Y. Lim, K. L. Ng, and S. Mat Junit, "Functional analyses of c.2268dup in thyroid peroxidase gene associated with goitrous congenital hypothyroidism," BioMed Research International, vol. 2014, Article ID 370538, 11 pages, 2014.

[26] C. C. Lee, F. Harun, M. Y. Jalaludin et al., "Variable clinical phenotypes in a family with homozygous c.1159G>A mutation in the thyroid peroxidase gene," Hormone Research in Paediatrics, vol. 81, no. 5, pp. 356-360, 2014.

[27] C. C. Lee, F. Harun, M. Y. Jalaludin, C. H. Heh, R. Othman, and S. M. Junit, "Prevalence of c.2268dup and detection of two novel alterations, c.670_672del and c.1186C > T, in the TPO gene in a cohort of Malaysian-Chinese with thyroid dyshormonogenesis," BMJ Open, vol. 5, no. 1, Article ID e006121, 2015.

[28] M. C. Vigone, S. Caiulo, M. Di Frenna et al., "Evolution of thyroid function in preterm infants detected by screening for congenital hypothyroidism," Journal of Pediatrics, vol. 164, no. 6, pp. 1296-1302, 2014.

[29] H. C. Woo, A. Lizarda, R. Tucker et al., "Congenital hypothyroidism with a delayed thyroid-stimulating hormone elevation in very premature infants: incidence and growth and developmental outcomes," Journal of Pediatrics, vol. 158, no. 4, pp. 538542, 2011. 


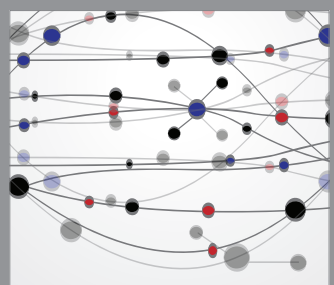

The Scientific World Journal
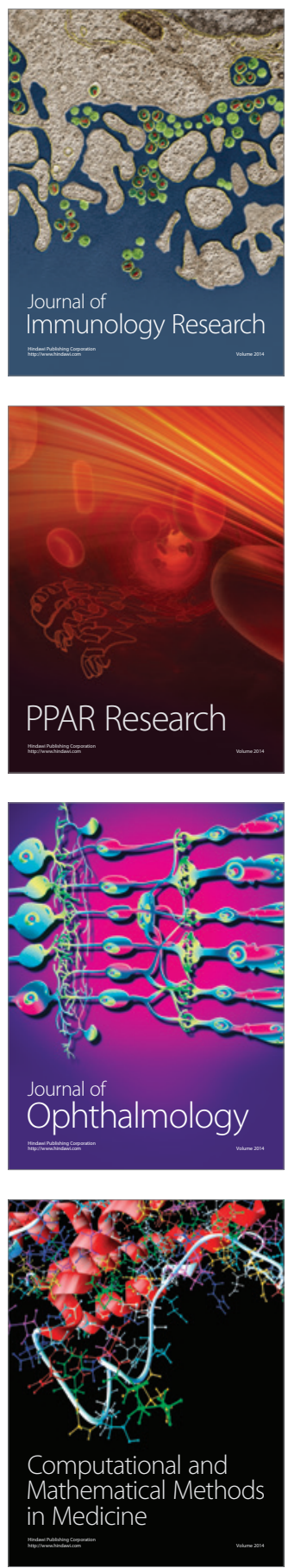

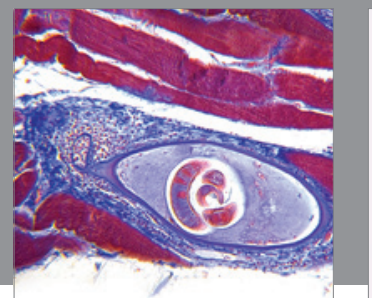

Gastroenterology

Research and Practice
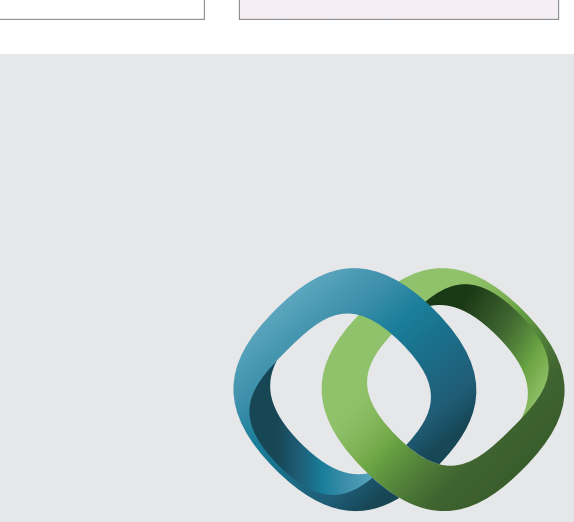

\section{Hindawi}

Submit your manuscripts at

http://www.hindawi.com
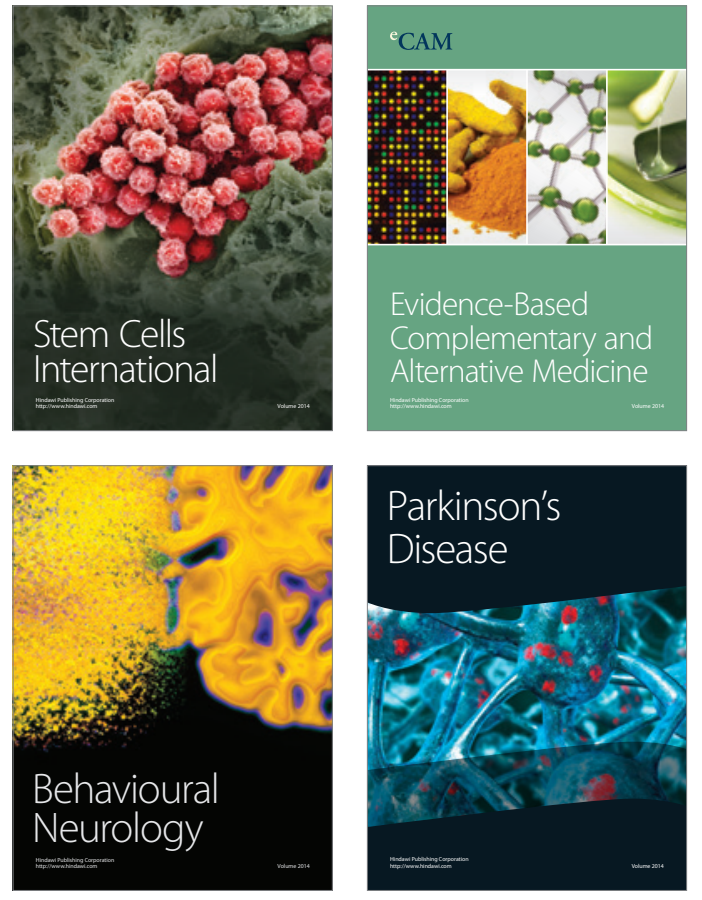
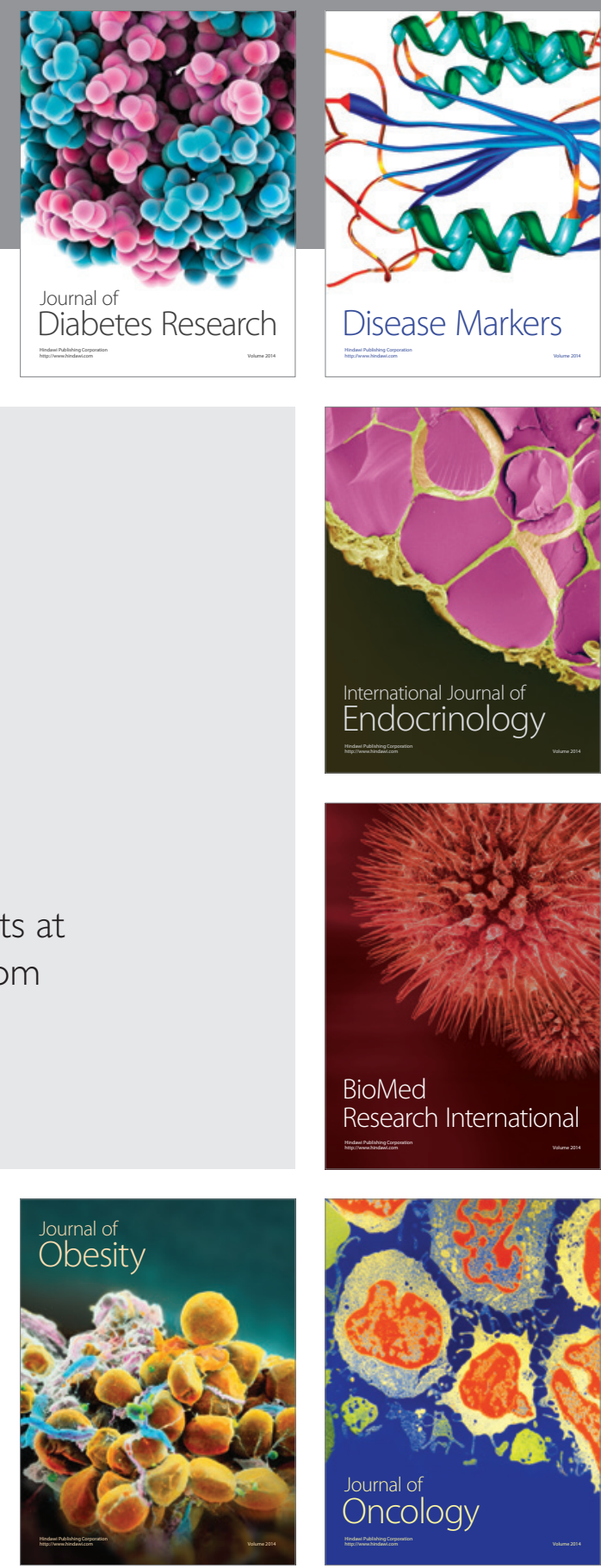

Disease Markers
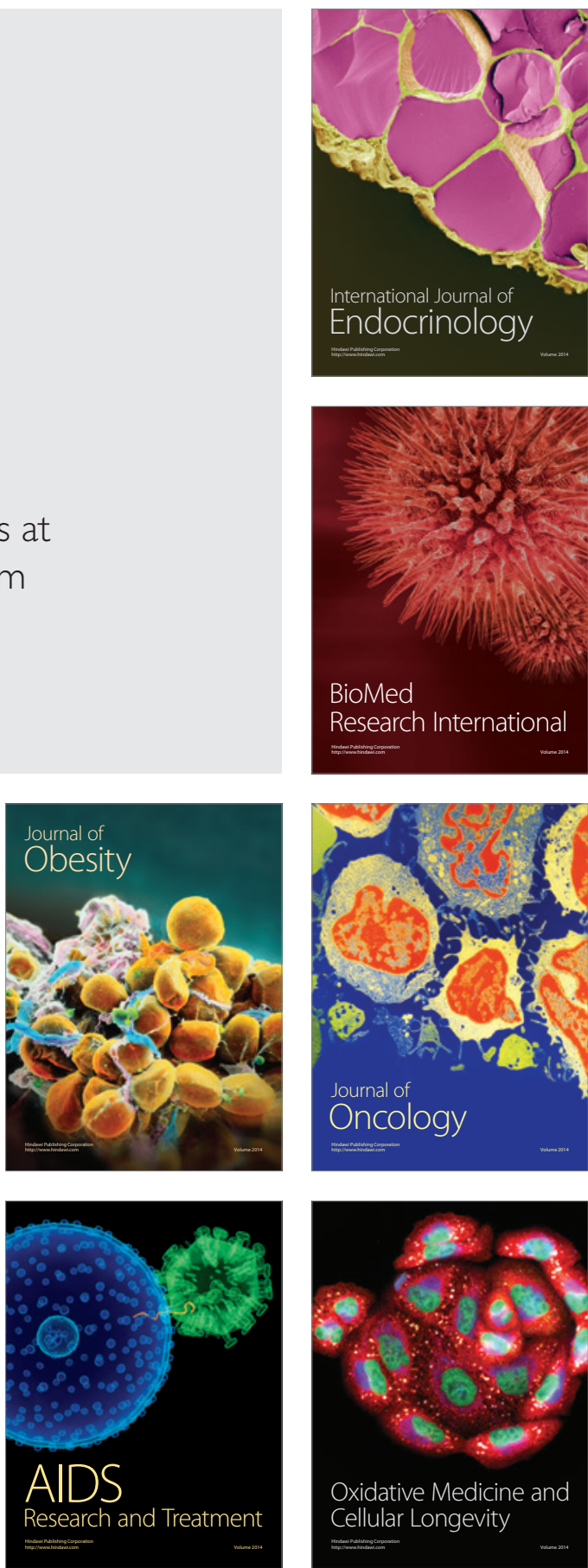